\title{
HEALTH PROMOTION BASED ON THE FIVE PRINCIPLES "PANCASILA" TO MANAGE AGGRESSIVE BEHAVIOR ON CAMPUS IN MALANG, EAST JAVA
}

\author{
Fattah Hanurawan, Indah Yasminum Suhanti, \\ Aryudho Widyatno
}

Universitas Negeri Malang

\begin{abstract}
Background: In recent years, access to information among adolescents has led to unlimited manifestation of aggression. Often this has been witnessed in the increasing number of adolescents institutionalized for aggressive behavior. This study aimed to investigate the five principles "Pancasila"-based health promotion to manage aggressive behavior among adolescents on campus in Malang, East Java.

Subjects and Method: A qualitative study was carried out on university campus in Malang, East Java. A total of 19 key informants was selected for this study, including teachers and students. The theme was application of the five principles "Pancasila"-based health promotion to manage aggressive behavior. The data were collected by literature study, in-depth interview, direct observation, and document review.

Results: (1) Aggressive behavior was managable under mental health promotion; (2) Mental health promotion can be provided in campus; (3) Mental health promotion is easier implemented if it is linked with local culture with the five principles "Pancasila" uniting various local cultures.

Conclusion: The five principles "Pancasila" can be used to plan a mental health promotion program aims to address aggressive behavior.
\end{abstract}

Keywords: five principles "Pancasila”, health promotion, aggressive behavior.

\section{Correspondence:}

Aryudho Widyatno. Universitas Negeri Malang, Malang, East Java.

Email: aryudhowidyatno.um@gmail.com. Mobile: 085807291202.

The 4th International Conference on Public Health

Best Western Premier Hotel, Solo, Indonesia, August 29-30, 2018 | 144 https://doi.org/10.26911/theicph.2018.02.25 